02

\title{
TRADITIONAL MITIGATION MEASURES AND PRACTICES TO CLIMATE CHANGE IN ROMBO DISTRICT, TANZANIA
}

\author{
Evarist Fundisha \\ Department of Geography, Mkwawa University College of Education, Iringa, Tanzania \\ Email: evarist_fundisha@yahoo.com
}

\begin{abstract}
Mitigation to climate change has been treated as an issue in developed countries whereas adaptation is seen as a priority for the developing countries. The study assessed the effectiveness of traditional mitigation measures and practices to climate change in Rombo District, Tanzania. Data were collected by questionnaire, interview and focus group discussion. Results indicate that the majority of household heads had resorted to tree planting aimed at mitigating climate change. The study found that education, land size and funds were among the stumbling blocks toward effective traditional mitigation measures and practices to climate change. The study recommends involvement of local people in tree planting campaigns coupled with awareness creation on the sustainable climate change mitigation at local levels.
\end{abstract}

Key words: Traditional Mitigation Measures and Practices, Climate Change

\section{Introduction}

Mitigation to climate change has been treated as an issue in developed countries, which account for the greatest responsibility for inducing climate change, whereas adaptation is seen as a priority for the South, where the capacity to mitigate is low with high vulnerability levels (Ayers and Huq, 2009). High vulnerability in the South is due to high proportion of aridity, widespread poverty, difficult socio-economic conditions, and heavy reliance of populations on natural resources. The South is also characterised by insufficient institutional and legal frameworks, weak infrastructural base and insufficient scientific, technical and educational capacity (UN, 1994). Mitigation refers to limiting global climate change through the reduction of the emissions of greenhouse gases (GHGs) and/or enhancing their sinks (Füssel and Klein, 2006). Traditional measures and techniques which mitigate climate change include agroforestry, mulching, fallowing, and cultural practices.

Agroforestry is defined as any land use system that involves the deliberate retention, introduction or a mixture of trees or other woody perennials with agricultural crops, pastures and/or livestock to exploit the ecological and economic interactions of the different components (Albrecht and Kandji, 2003). Agroforestry involves a tree-based system such as the jungle rubber system of Sumatra, the mixed cocoa and fruit tree plantations of Cameroon, peach palm systems of Peru or the pine-banana-coffee of eastern Java (Verchot et al., 2007). In the West African Sahel, agroforestry consists mainly of intercropping agricultural crops under scattered mature tree that are selectively retained by farmers because of the variety of non-timber uses such as food and medicine (Takimoto et al., 2010). Apart from carbon sequestration potentials, agroforestry also provides food, firewood, and shade to crops. Other benefits include plant nutrients, biomass for mulch and protection from wind and water erosion and boundaries demarcation (Albrecht and Kandji, 2003). This indicates that agroforestry facilitates mitigation and adaptation to climate change. This argument is similar to Salazar et al.'s (2011) to the effect that agroforestry system has been a solution to farming problems experienced on degraded soils because of their secondary environmental benefits such as promoting ecological diversity and improving the economy of the impoverished farmers who live in the inner rain-fed zone of central Chile. Kiptot et al. (2007) also attest to the fact that the deliberate planting of fast- 
growing leguminous trees or shrubs in rotation with crops have great potential in improving soil fertility in areas where nitrogen deficiency is the main fertility constraint thereby improving farmers' income and hence food security.

In West African Sahel, there is live fence, which involves planting of fast-growing trees in high density around the field plots, and protecting the fields from roaming animal because animal production is an integral part of agriculture and livelihood (Takimoto et al., 2008). The same authors, however, found that farmers in the West African Sahel were unlikely to increase the tree density to sequester more carbon because trees are raised through natural regeneration and too many trees may negatively impact crop production from farmlands. Similarly, farmers in Vihiga, Kenya, were unwilling to forego growing of seasonal crops to give way to trees whose benefits are not immediate (Kiptot et al., 2007). It has been noted by Verchot et al. (2007) that the prosperity of agroforestry is determined by the certainty of rainfall in a particular area. Shemsanga et al. (2010) insist that rainfall is scarce and many trees grow with difficulty and take longer to grow. Agroforestry practices such as shifting cultivation and pasture maintenance by burning may favour the emission of GHGs (Albrecht and Kandji, 2003), hence contributing even further to climate change.

Other traditional measures and practices which mitigate climate change are cultural practices. A study conducted by Anthony (2006) in Mara Region, Tanzania, revealed that cultural practices such as ritual activities mitigate climate change as only ethnic religious leaders have access to and utilise forest and forest products where ritual activities are carried out. These practices encourage conservation of forests, which promote carbon sequestration and, hence, mitigating climate change. Speraza et al. (2010) found that sacred forests established under traditional urge the modern state to support such tradition by declaring sacred forests protected areas. A study conducted in India by Srinivasan (2004) established that community regulations such as banning the cutting of certain types of trees or religious decrees that declare certain trees to be sacred play a big role in maintaining ecosystem health and facilitates mitigation to climate change.

Climate of Rombo District has been changing over time. Meena and O'Keefe (2007) report an average decrease of about $300 \mathrm{~mm}$ of rainfall from 1974 to 2004 . The same authors reported a rise of one degree centigrade in the annual mean temperature over the same period. Such changes had resulted into recurrent droughts in the district leading into the differentiated food insecurity, water shortages and pasture deterioration (Fundisha, 2019, Fundisha, 2017 and Mongula, 2000) Despite the impacts exerted by these changes to the ecosystem, studies on how local people mitigate climate change in the study area are not readily available. The present study, therefore, assessed the efficacy of traditional mitigation measures and practices to climate change in Rombo District, Tanzania as a basis for achieving sustainable development.

\section{Research Methodology}

This study was carried out in Rombo District, Tanzania. The district experiences variation in rainfall and temperature, leading to two main agroecological zones (AEZs) with a transition zone in between. The transition zone possesses characteristics of the main AEZs. The AEZs based on the criteria aforementioned are the highland AEZ $(1900-1500 \mathrm{~m})$, the intermediate AEZ $(1500-1200 \mathrm{~m})$ and the lowland AEZ (1200 - 500m) (Figure 1). Primary data were collected using the questionnaire, interviews, observations and focus group discussions. The use of different tools to collect data is based on the assumption that the data to be collected are both qualitative and quantitative in nature. On the other hand, secondary data and information 
relevant to the study topic were reviewed from the peer reviewed and accredited international and local journals, technical reports and books.

Qualitative data from the questionnaire, interviews, observations and focus group discussions were organised into themes and presented mainly in narrative form. Quantitative data, on the other hand, were organised into independent and dependent variables and analysed with the help of the Statistical Package for Social Sciences Version 16 to generate frequencies and percentages. Frequencies and percentages were further cross-examined with the selected characteristics of heads of household (i.e. to include agro ecological location, age, sex, level of education and marital status) to determine their relationship. These data were presented in the frequency tables to simplify interpretations.

Figure 01: Study Areas

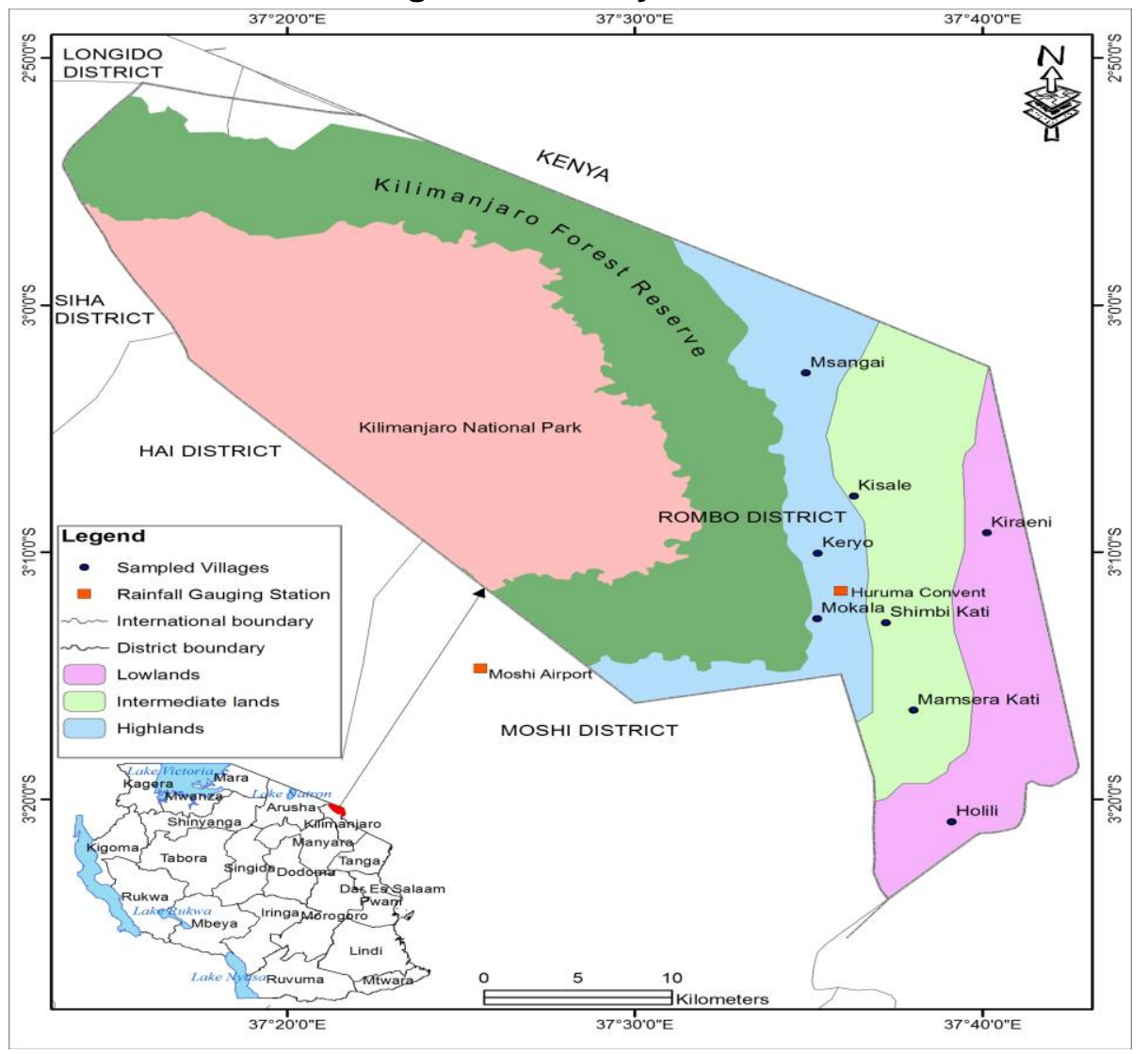

\section{Results}

As climate change is mainly induced by deforestation, their mitigation should concentrate on reforestation and afforestation programmes. The responses on traditional mitigation measures to climate change provided during the heads of household interview are listed in Table 1. The table shows that mitigation measures to climate change vary between $A E Z$ and with socioeconomic characteristics of the heads of household. It was noted during the FGDs and direct questionnaire survey administration that planting indigenous trees is important in mitigating climate change than exotic ones. In-depth interview with the VEO at Msangai Village revealed that individuals of the study area have a tradition of planting trees for different purposes. Trees are planted for fodder, providing shade for coffee, fruits, timber, farm demarcation, and currently for cash. The tradition of planting trees was confirmed during interviews with the heads of household that "I am now aware trees mitigate climate change. I acquired this knowledge from our priest; also from village meetings and radios. Initially, I planted trees for fodder, building materials, firewood and farm demarcation but now are for climate change mitigation" 
Table 01: Mitigation Measures to Climate Change

\begin{tabular}{|c|c|c|c|c|}
\hline \multirow{2}{*}{$\begin{array}{l}\text { Characteristics } \\
\text { of Heads of } \\
\text { Household }\end{array}$} & \multicolumn{4}{|c|}{ Responses on Measures (\%) } \\
\hline & Planted trees & $\begin{array}{c}\text { Avoid } \\
\text { indiscriminate } \\
\text { tree felling }\end{array}$ & Praying & $\begin{array}{c}\text { No measures } \\
\text { devised }\end{array}$ \\
\hline \multicolumn{5}{|l|}{ Location (AEZ) } \\
\hline Highland & 66.7 & 18.3 & 5.6 & 9.5 \\
\hline Intermediate & 58.7 & 32.3 & 6.0 & 3.0 \\
\hline Lowland & 53.4 & 27.6 & 3.4 & 15.5 \\
\hline \multicolumn{5}{|l|}{ Education level } \\
\hline Primary & 61.4 & 27.0 & 4.7 & 6.9 \\
\hline Secondary & 68.8 & 22.9 & 8.3 & 0.0 \\
\hline Post-Secondary & 86.7 & 13.3 & 0.0 & 0.0 \\
\hline No formal & 39.6 & 24.5 & 11.3 & 24.5 \\
\hline \multicolumn{5}{|l|}{ Age Group } \\
\hline Youths (15-34) & 81.9 & 10.3 & 2.6 & 5.0 \\
\hline Adults (35-64) & 62.7 & 25.5 & 5.6 & 6.2 \\
\hline Elders $(65+)$ & 48.3 & 27.0 & 7.9 & 16.9 \\
\hline \multicolumn{5}{|l|}{ Sex } \\
\hline Male & 63.0 & 26.5 & 4.4 & 6.2 \\
\hline Female & 48.5 & 24.8 & 10.9 & 15.8 \\
\hline \multicolumn{5}{|l|}{ Marital Status } \\
\hline Married & 61.3 & 26.9 & 5.1 & 6.6 \\
\hline Singles & 65.9 & 21.4 & 5.4 & 7.1 \\
\hline Total $(\mathrm{N}=611)$ & 63.58 & 21.9 & 5.9 & 8.7 \\
\hline
\end{tabular}

Source: Field Data

The testimony above revealed that, tree planting in the study area owed its origin from the long standing tradition associated with the importance of trees in the community. The tradition of planting trees was confirmed during field observation where almost every household practised agroforestry. Common trees found in the study area were Gravellia robusta, Sedrela odorata, Glirricidia sp. and Casuarina sp. (for timber); Milicia exselsa and Accacia sp. (for soil fertility); Podocarpas sp. and Agrocarpas sp. (for medicine); Laucaena sp. (for fodder); and Senna siamea (for firewood). The efficacy of tree planting was mostly rated by the heads of household to be very effective compared to other measures to climate change (Table 2). The FGDs conducted in the intermediate and lowland AEZs and in-depth interviews held with VEOs at Kisale and Kiraeni villages, however, revealed that it was difficult to raise tree seedlings without watering due to erratic rainfall. A similar case was reported during an in-depth interview with the AEO in Kisale-Msaranga Ward. This was also affirmed during field observation where dried trees were seen in the lowland AEZ. During an interview with a head of household at Holili Vijijini, it emerged that some households hesitated to plant trees supplied to them because they were neither preferred by livestock for fodder nor suitable for firewood. Also, the trees were not suitable for agroforestry because they limit the growth of crops underneath. Furthermore, it was noted during an interview with a head of household at Msangai Village that tree planting was also affected by theft and lack of money to buy suitable seedlings.

Furthermore, during interviews with government officials in the study area it was established that in 2000, the district enacted a bylaw which prohibits the felling of indigenous trees without securing permit. But following a meeting held in the Kilimanjaro Regional Commissioners' Office on $29^{\text {th }}$ February, 2012 between researchers from the University of Dares Salaam and the leaders of the region, consensus was reached that all the trees must be protected by the bylaw. The research team held that the wanton felling of trees in Kilimanjaro Region contributed to increased temperature and the attendant consequences. The 
consequences of increased temperature led to unprecedented melting of ice at the top of Mt. Kilimanjaro, unpredictable rainfall regime and increased wind strength.

Table 2: Effectiveness of Mitigation Measures to Climate Change

\begin{tabular}{|c|c|c|c|c|c|c|c|c|c|}
\hline \multirow{3}{*}{$\begin{array}{l}\text { Characteristics } \\
\text { of Heads of } \\
\text { Household }\end{array}$} & \multicolumn{9}{|c|}{ Responses on Efficacy (\%) } \\
\hline & \multicolumn{3}{|c|}{ Planted trees } & \multicolumn{3}{|c|}{$\begin{array}{l}\text { Avoid indiscriminate } \\
\text { tree felling }\end{array}$} & \multicolumn{3}{|c|}{ Praying } \\
\hline & VE & $E$ & $\mathrm{NE}$ & VE & $\mathrm{E}$ & $\mathrm{NE}$ & VE & $E$ & $\mathrm{NE}$ \\
\hline \multicolumn{10}{|l|}{ Location (AEZ) } \\
\hline Highland & 31.4 & 68.6 & 0.0 & 28.3 & 71.7 & 0.0 & 23.8 & 76.2 & 0.0 \\
\hline Intermediate & 46.2 & 53.8 & 0.0 & 37.5 & 61.7 & 0.8 & 25 & 75 & 0.0 \\
\hline Lowland & 62.3 & 37.7 & 0.0 & 30.8 & 64.1 & 5.1 & 0.0 & 100 & 0.0 \\
\hline \multicolumn{10}{|l|}{ Age Group } \\
\hline Youths (15-34) & 77.5 & 22.5 & 0.0 & 13.7 & 31.8 & 4.6 & 8.4 & 41.7 & 0.0 \\
\hline Adults (35-64) & 38.1 & 61.7 & 0.0 & 0.0 & 33.0 & 65.2 & 1.8 & 23.3 & 0.0 \\
\hline Elders $(65+)$ & 53.2 & 46.8 & 0.0 & 37.9 & 62.1 & 0.0 & 25 & 75 & 0.0 \\
\hline \multicolumn{10}{|l|}{ Sex } \\
\hline Male & 42.2 & 57.8 & 0.0 & 32.4 & 66.5 & 1.1 & 21.9 & 78.1 & 0.0 \\
\hline Female & 44.8 & 55.2 & 0.0 & 41.2 & 55.9 & 2.9 & 23.1 & 76.9 & 0.0 \\
\hline \multicolumn{10}{|l|}{ Education } \\
\hline Primary & 40.5 & 59.5 & 0.0 & 32.8 & 65.6 & 1.6 & 11.8 & 88.2 & 0.0 \\
\hline Secondary & 51.3 & 48.7 & 0.0 & 47.7 & 52.9 & 0.0 & 50 & 50 & 0.0 \\
\hline Post-Secondary & 53.3 & 46.7 & 0.0 & 50 & 50 & 0.0 & 0.0 & 0.0 & 0.0 \\
\hline No Formal & 54.5 & 45.5 & 0.0 & 26.7 & 73.3 & 0.0 & 57.1 & 42.9 & 0.0 \\
\hline \multicolumn{10}{|l|}{ Marital Status } \\
\hline Married & 41.6 & 58.4 & 00 & 33 & 65.5 & 1.5 & 16.2 & 83.8 & 0.0 \\
\hline Singles & 53.8 & 46.2 & 0.0 & 35.5 & 44.5 & 0.0 & 22.0 & 38.0 & 0.0 \\
\hline TOTAL $(\mathrm{N}=611)$ & 49.3 & 50.7 & 0.0 & 32.0 & 57.0 & 5.9 & 20.4 & 60.7 & 0.0 \\
\hline
\end{tabular}

The findings from government officials in the study area further show that a permit to fell a tree is applied to the District Executive Director (DED) through the VEO of the respective village. The DED appoints a team to visit the area to determine whether the incumbent application satisfies the stipulated rules. It includes concrete reasons for felling a tree such as for building a house or avoiding danger associated with the tree. The danger could be to human beings and fixed assets such as houses due to the location and age of a tree. A permit to fell a tree is granted once the DED is satisfied with the recommendations from the team. It was also revealed during in-depth interview with the VEO from Kisale Village that the village has established completion among the villagers on environmental conservation by focussing on mainly tree planting. The prizes were at household level where those emerged outstanding on the matter were given some farm implements.

Table 2 shows that mitigating climate change by avoiding indiscriminate tree felling was the only aspect rated as ineffective. Interviews with heads of household at Keryo Village indicate that tree felling is inevitable due to the growing market for timber and demand for firewood. The ineffectiveness of this measure was also raised during interviews with heads of household at Mamsera Kati Village. In this regard, one head said: "Some government officials are involved in lumbering and some own chain-saw machines....do you think these [government officials] will stand firmly to make sure indiscriminate tree halt?' Also, the FGDs highlight the difficulty of avoiding tree felling because the majority of households sell trees to raise money for food, school fees and medical services. Furthermore, Table 1 shows that praying as a mitigation measure to climate change was mostly mentioned by the heads of household without formal education and females. Praying was mostly rated as an effective measure for mitigating climate 
variability than other measures (Table 2). Nonetheless, Table 1 also shows that among the heads of household who mentioned having devised no measures to mitigate climate change. The majority of these respondents were those without any formal education. There was no head of household with secondary and post-secondary education who had not devised measures to mitigate climate change. These results show that mitigating climate change is influenced by characteristics of heads of household.

\section{Discussion}

Studies by Mertz et al. (2009) and Kemausuor et al. (2011) reveal that community awareness of the causes of climate change constitutes a stepping stone in the formulation and implementation of mitigation measures. Any mitigation of climate change including carbon sequestration in developing countries should target the forests and land use sector because they are major contributors to greenhouse gas (GHG) emissions (Shemsanga et al., 2010). The tree planting mentioned in this study is consistent with the Tanzania government attempt to increase GHGs sequestration (URT, 2007). It is important, however, to note that tree planting in the study area owed its origin to tradition rather than to its current function of mitigating climate change. Trees in the study area are planted to provide fodder for zero-grazing livestock, land demarcation, coffee shading, and fruit production. Others are slope stabilisation, firewood, building materials, and cash value.

Zero-grazing livestock requires a constant supply of fodder whereby trees and grass are planted to cater for these requirements. Because land in the study area is very expensive, households have decided to plant trees and herbs at boundaries to avoid encroachment by their neighbours, which could lead into conflict. Also, some trees were planted to provide shade to coffee plants and at the same time protect property from wind destruction. However, due to the declining coffee production caused by poor market and climate change (Meena and O'Keefe, 2007), planting trees for shade might also experience a similar trend. The slopping land in the study area may, as well, necessitate measures to control soil erosion, which include tree planting. Households in the study area also plant trees, hoping to get fruits and timber for household use or for cash. As it was pointed out during in-depth interview with the AEO in Kisale-Msaranga ward, timber is an important source of income for the majority of the people in the study area. Environmental and economic importance of agroforestry has also been mentioned by Albrecht and Kandji (2003), Takimoto et al. (2010) and Salazar et al. (2011). Kangalawe et al. (2011) also found that local people in the Great Ruaha Catchment area in Tanzania planted trees to conserve water without knowing they were mitigating climate change.

Yanda and Mubaya (2013) underscore a difficulty inherent in assessing how much forest degradation can be avoided because of the complexities and controversies related to the socioeconomic aspect of a particular region. As for this study, environmental conservation by avoiding indiscriminate tree felling might prove difficult in maintaining because all the respondents mentioned firewood as the main source of energy. Cooking by placing a cooking pot on three stones and burning firewood underneath wastes much of the heat generated and produces a lot of smoke that was unpalatable to good health. The large amount of heat lost in cooking implies more cutting down of trees and, consequently, environmental degradation. This may also lead to more time spent on collecting firewood or more money to buy the same. Smoke produced during cooking contributes to increased GHGs emission thereby amplifying climate and weather changes. Similar findings have been reported by Enete and Amusa (2010), who show that the use of firewood increases the concentrations of greenhouse gases in the atmosphere trapping heat and, hence, inducing climate change. 
The prizes established at Kisale Village for individuals with outstanding effort in environmental conservation, particularly tree planting echoes the one under REDD plus whereby individuals or groups who plant many trees get rewards (REDD net, 2009). Financing environmental conservation is also stipulated in the Kyoto Protocol whereby forests established after 1990 purposely for climate change mitigation are eligible for carbon offsets (Yanda and Mubaya, 2013). This strategy should not be ignored although it is undermined by land fragmentation whereby most people hesitated to plant more trees claiming to limit the smooth growth of food crops. Similar findings have been reported by Kiptot et al. (2007) who found that tree planting in Siaya and Vihiga districts in Kenya was not successful due to small land sizes and people who were not willing to plant trees at the expense of food crops. Takimoto et al. (2008) also report that too many trees have a negative impact on crop production. The impacts of tree planting on crop production are more severe in dry environments because trees compete with crops for water (Albrecht and Kandji, 2003). Codjoe et al. (2012) in their studies carried out in the Afram Plains of Ghana found that people were reluctant to plant trees because trees take a long time to grow, occupied space suitable for crop production and were not edible.

The findings from this study revealed that the future existence of trees particularly in the lowland AEZ faces a bleak future because it is impossible to raise trees without watering due to recurrent drought. The recently introduced environmental bye-law, which requires one to obtain a permit to fell a tree and the government order to plant trees, might facilitate the implementation of the tree planting programme. However, full implementation of these strategies may intensify food insecurity because many trees limit the land available for crop production.

\section{Conclusion}

The study community understand that trees are very important in mitigating climate change. It was established that tree planting needs large tracts of land because trees compete with food crops thereby lowering crop yields. The future prospect of trees was found to be undetermined due to small land sizes, unavailability of tree seedlings, the growing market for timber and increased climate change. Afforestation and reforestation programmes should be emphasised to facilitate sustainable mitigation to climate change. In this regard, suitable trees for planting including those which increase soil fertility, edible and fast growing should be encouraged. Rural electrification and capacity-building are important in enabling rural communities to use electricity to curtail indiscriminate tree felling. Continuing education is also necessary for sustained awareness of the consequences of human action in the course of interaction with the environment. Such awareness can lead to the change of attitude. Environmental bylaws should be established by involving local people in inculcating a sense of participation for smooth implementation. If possible, the traditional environmental bylaws should be revitalised. Prizes for outstanding efforts on environmental conservation should be an integral part of motivation to increase participation in environmental management initiatives.

\section{References}

1. Albrecht, A. and Kandji, S. T. (2003). Carbon Sequestration in Tropical Agroforestry Systems. Agriculture, Ecosystems and Environment Vol. 99 pp. 15-27.

2. Anthony, R. (2006). Traditional Environmental Knowledge Systems related to Changes and Variations of Water Resources Management in Semi-Arid, Tanzania. A Case of Mara River Basin. A thesis submitted in fulfilment of the requirements for the degree of Doctor of Philosophy of the University of Dar es Salaam.

3. Ayers, J. M. and Huq, S. (2009). The Value of Linking Mitigation and Adaptation: A Case Study of Bangladesh. Environmental Management Vol. 43 pp. 753-764.

4. Codjoe, S. N. A., Atidoh, L. K. and Burkett, V. (2012). Gender and Occupational Perspectives on Adaptation to Climate Extremes in the Afram Plains of Ghana. Climatic Change Vol. 110 pp. 431-454. 
5. Enete, A. A. and Amusa, T. A. (2010). Challenges of Agricultural Adaptation to Climate Change in Nigeria: A Synthesis from the Literature. Field Actions Science Reports Vol.

6. Fundisha, E. (2017). Livestock Management Strategies in a Changing climate in Rombo District, Tanzania. Journal of Global Resources Vol. 5 pp. 109-115

7. Fundisha, E. (2019). Assessment of Traditional Environmental Knowledge Systems Applied to Climate Change and Variability Adaptation in Rombo District, Tanzania. Journal of Global Resources Vol. 5(02) pp. 20-28

8. Füssel, M. H. and Klein, R. J. T. (2006). Assessing Vulnerability and Adaptation to Climate Change: An Evolution of Conceptual Thinking. Climatic Change Vol. 75 pp. 301-329.

9. Kangalawe, R., Mwakalila, S. and Masolwa, P. (2011). Climate Change Impacts, Local Knowledge and Coping Strategies in the Great Ruaha River Catchment Area, Tanzania. Natural Resources Vol. 2 pp. 212-223

10. Kemausuor, F., Dwamena, E., Part-Plange, A. and Kyei-Baffour, N. (2011). Farmers' Perception of Climate Change in the Ejura-Sekyedumase District of Ghana. Journal of Agricultural and Biological Science Vol. 6 (10)

11. Kiptot, E., Hebinck, P., Franzel, S. and Richards, P. (2007). Adopters, Testers or Pseudoadopters? Dynamics of the Use of Improved Tree Fallows by Farmers in Western Kenya. Agricultural Systems Vol. 94 pp. 509-519.

12. Meena, H. E. and O'Keefe, P. (2007). Sustainable Livelihoods in the Context of Vulnerability and Adaptation to Climate Change Impacts in Tanzania: A Case Study of Kilimanjaro Region. The Netherlands Climate Association Program, Netherlands.

13. Mertz, O., Mbow, C., Reenberg, A. and Diouf, A. (2009). Farmers' Perceptions of Climate Change and Agricultural Adaptation Strategies in Rural Sahel. Environmental Management Vol. 43 pp. 804-816.

14. Mongula, B. (2000). Food Security, Appropriate Technology and Micro-Industry: The Case of Drought Areas of Rombo District in Tanzania. Institute of Development Studies, University of Dar es Salaam.

15. REDD Net (2009). Visioning REDD+ in East Africa: A Focus on Benefit Sharing in Uganda and Tanzania. REDD-Net East Africa Bulletin (01) 11p. December 2009.

16. Salazar, O., Casanova, M. and Kättere, T. (2011). The Impact of Agroforestry Combined With Water Harvesting on Soil Carbon and Nitrogen Stocks in Central Chile Evaluated Using the ICBM/N Model. Agriculture, Ecosystems and Environment Vol. 140 pp. 123-136.

17. Shemsanga, C., Omambia, A. N. and Gu, Y. (2010). The Cost of Climate Change in Tanzania: Impacts and Adaptations. Journal of American Science Vol. 6 (3).

18. Speranza, C. I., Kiteme, B., Ambenje, P., Wiesmann, U. and Makali, S. (2010). Indigenous Knowledge Related to Climate change: Insights from Droughts in Semi-arid Areas of former Makueni District, Kenya. Climatic Change Vol. 100 pp. 295-315.

19. Srinivasan, A. (2004). Local Knowledge for Facilitating Adaptation to Climate Change in Asia and the Pacific: Policy Implications. Working Paper Series No. 002. IGES Climate Policy Project.

20. Takimoto, A., Ramachandran, N. and Nair, V. D. (2008). Carbon Stock and Sequestration Potential of Traditional and Improved Agroforestry Systems in the West African Sahel. Agriculture, Ecosystems and Environment Vol. 125 pp. 159-166.

21. United Nations (UN, 1994). Intergovernmental Negotiating Committee for the Elaboration of an International Convention to Combat Desertification in Countries Experiencing Serious Drought and/or Desertification, Particularly in Africa. A/AC.241/27. http://www.unccd.int /Lists/Site Document Library/ convention Text/conv-eng.pdf. Retrieved on $20^{\text {th }}$ August 2014.

22. United Republic of Tanzania (URT, 2007). National Adaptation Programme of Action (NAPA) for Tanzania. Division of Environment. http/:unfccc.int/ resource/doc/ napatza01.pdf. Retrieved on $28^{\text {th }}$ May 2010.

23. Verchot, L. V., Noordwijk, M. V., Kandji, S., Tomich, T., Ong, C., Albrecht, A., Mackensen, J., Bantilan, C. Anupama, K. V. and Palm, C. (2007). Climate Change: Linking Adaptation and Mitigation through Agroforestry. Mitigation and Adaptation Strategies to Global Change Vol. 12 pp. 901-918.

24. Yanda, P. Z. and Mubaya, C. P. (2013). Managing a Changing Climate in Africa: Local Level Vulnerabilities and Adaptation Experiences. Mkuki na Nyota, Dar es Salaam. 